\title{
Implikasi Perdagangan Bebas APEC pada Perekonomian Indonesia
}

\author{
Oleh : Nur Feriyanto
}

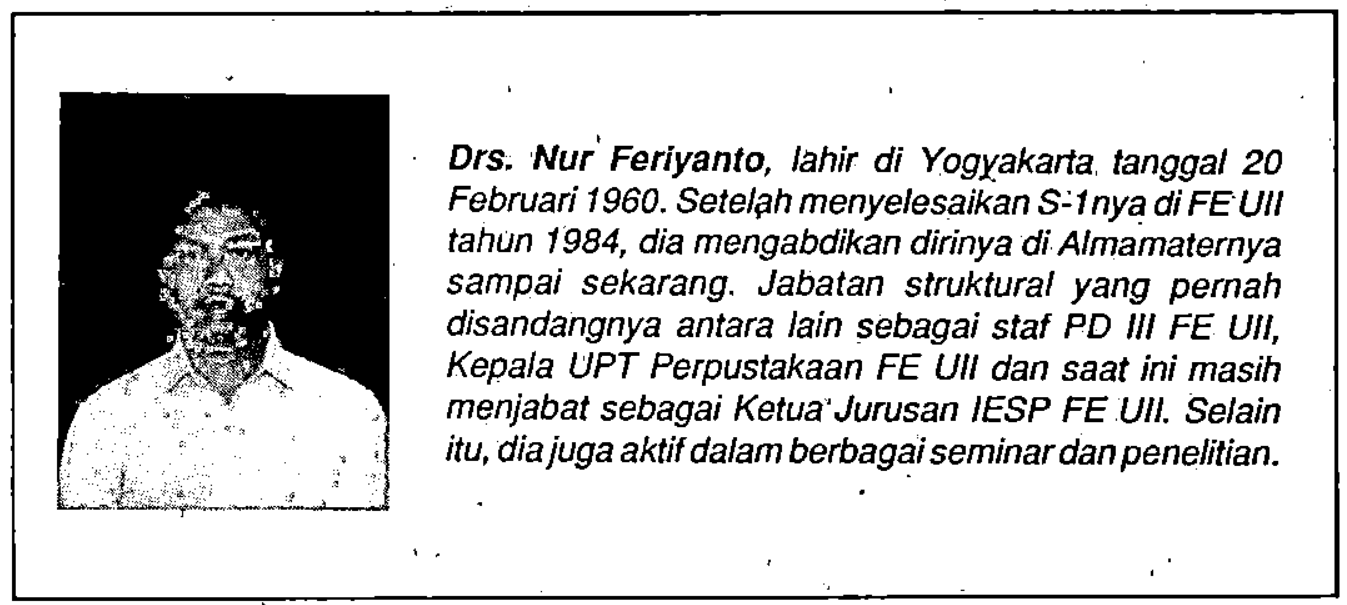

Pendahuluan

Pertemuan 18 pimpinan negara Asia Pasific dalam APEC telah berakhir pada tanggal 15 Nopember 1994 dengan melahirkan Deklarasi Bogor (Declaration on Common Resolve). Deklarasi tersebut telah merumuskan arah dan rancangan masa depan kerjasama ekonomi yang akan memperbaiki prospek pertumbuhan ekonomi yang dipercepat, seimbang dan merata di kawasan Asia Pasific. Kerjasama ekonomi tersebut meliputi liberalisasi perdagangan dan investasi serta pembangunan ekonomi.

Indonesia yang sedang tumbuh cepat dalam pembangunan ekonominya makin lama makin menunjukkan perannya dalám kawasan Asia Pasific. Hal ini dapat dilihat dari pertumbuhan ekonomi yang cukup tinngi $7 \%$ per tahun, jumiah penduduk
.191,6 juta pada tahun 1993 dan dengan tingkat kestabilan dan keamanan yang mantap, sehingga tahun 1994 Indonesia dipercaya menjadi tuan rumah APEC. Tetapi tidak dapat dipungkiri bahwa Indonesia masih mempunyai kinerja ekonomi yang belum efisien dalam aktivitas ekonominya.

Tulisan ini akan memberikan gambaran tentang kemampuan Indonesia dalam mengantisipasi Perdagangan Bebas APEC.

Perkembangan Penyusunan Deklarasi Bogor

Sebelum diadakannya AELM (APEC Economic Leaders Meeting) yang melahirkan Deklarasi Bogor, pertemuan telah diawali oleh EPG (Eminent Persons Group) atau kelompok tokoh terkemuka 
APEC dan PBF (Pacific Business Forum), terdiri dari parapemimpinduniausaha-dunia usaha negara APEC. Dua kelompok ini membahas tentang pelaksanaan liberalisasi perdagangan dan investasi di Asia Pasific.

Hasil yang diperoleh EPG dalam laporannya yang berjudul: "Achieving the APEC Vision: Free and open Trade in the Asia Pacific"; merekomendasikan dimulainya prosesliberalisasi perdagangan pada tahun 2000 dan berakhir tahun 2020. EPG menetapkan dimulainya liberalisasi perdagangan dan investasi yang berbeda untuk kondisi negara yang beibeda. Untuk negara maju seperti Amerika dan Jepang perdagangan bebas dan investasi dimulai pada tahun 2005. Bagi negara-negara industri baru seperti Korea Selatan, Hongkong, Taiwan dan Singapura penerapan liberalisasi perdagangan dan investasi dimulai pada tahu 2015, tetapi untuk negara yang sedang berkembang seperti Indonesia perdagangan bebas secara penuh dan investasi diusulkan mulai tahun 2020. Sedangkan oleh PBF dalam laporannyaberjudul: "A Business Blueprint for APEC" mengusulkan dimulainya perdagangan penuh dan investasi mulai tahun 1994, dan selesai tahun 2010 untuk negara-negara mäju serta tahun 2020 untuk negara-negara berkembang.

Dari kedua laporan tersebut kemudian menjadi bahan bagi pertemuan KTM (Konferensi Tingkat Menteri) VI APECyangkemudianmenyerahkankepada AELM dalam pertemuannya di Bogor. Hal akhir yang diltelurkan oleh AELM dengan namá Deklarasi Bogor adalah dibukanya perdagangan bebas dan investasi selambatlambatnya tahun 2010 untuk negara maju dan tahun 2020. untuk negara sedang berkembang di Asia Pasific dengan mengacu pada semangat, GATT (WTO). Disamping itu untuk mendukung deklarasi tersebut para pimpinan ekónomi mẹmandang perlu untuk meningkatkan kerjasama di bidang peningkatan infrastruktur ekonomi, ilmu pengetahuan dan teknologi, pengembangansumber daya ekonomi, lingkungan pengembangan usaha kecil dan menengah serta mengaktifkan keikut sertaan pihak swasta.

Harapan yang optimis akan keberhasilan kerjasama tersebut akan muncul dengan melihat indikator ekonomi dari 18 negara angoota APEC (tabel 1). Kawasan Asia Pasific mempunyai populasi yang cukup tinggi, tiga dari lima negara yang berpenduduk terbesar dunia terletak di kawasan ini. Penduduk RRC dengan jumlah populasi sebesar 1.196,5 juta, Amerika Serikat dengan penduduk 260,6 juta dan Indonesia dengan populasi 191,6 juta, menjadikan kawasan ini merupakan pasar yang cukup besar untuk menyerap pródukdanjasa yang dihasilkan darinegaranegara anggota $A P E C$ tersebut. Disamping itu kapasitas sumber daya manusia yang cukup besar itu adalah faktor produksi yang potensial untuk mendukung gerak maju aktivitas ekonomi kawasan ini yang hampir menguasai $60 \%$ PDB dunia.

Perkembangan dinamis dari GNP negara-negara anggota APEC dengan ratarata pertumbuhan 6-7 \% pertahun menjanjikan kawasan Asia Pasific adalah kawasan potensial bagi pertumbuhandunia usaha. Darikondisi negaranyapunkawasan ini juga 'merupakan kawasan dengan komposisi negará yang cukup lengkap. Untuk golongan negara dengan tingkat pertumbuhan maju adalah Amerika Serikat, 
Jepang dạn Kanada dengan GNP pér kapita di atas 20.000 ,US\$. Sedangkan negaranegara industri baru diantaranya adalah negara Taiwan, Hongkong, Korea Selatan, dan Singapura. Terdapat pula kelompok negara sedang berkembang denganprospek yang baik yaitu Indonesia, RRC, Malaysia, Thailand dan Filipina. Dengan kondisi tersebut perkembangan ekonomi kawasan ini sangat potensial, karena antar negara tersebut akan saling mengisi dan mengadakan kerjasama yang saling. menguntungkan. Tentunya nilai-nilai indikator tersebut dapat bérubah menjadi lebih baik bilamana perdagangan bebas antar pimpinan negara tersebut tentunya akan mempunyai implikasi yang harus diantisipasi oleh Indonesia baik oleh pihak Pemerintah ataupun swasta' khususnya dalam peningkatan pertumbuhan ekonomi yang berkelanjutan, dengan tetap mengacu pada perjanjian GATT yang telah diratifikasi di Marrakesh (Maroko) yang nantinya mulai 1 Janüari 1995 akan berubah menjadi WTO(World-Trade Organization).

\section{Perdagangan Indonesia dalam APEC} Meskipun waktu pelaksanaan perdagangan bebas dan investasi masih 26 tahun lagi (tahun 2020), tetapi Pemerintah

Tabel 1 Indikator Ekonomi 18 Negara Anggota APEC Tahun 1993

\begin{tabular}{|c|c|c|c|c|c|c|c|}
\hline NAMA NEGARA & $\begin{array}{r}\text { POPULASI } \\
\text { (JUTA) }\end{array}$ & $\begin{array}{r}\text { GDP } \\
\text { (USSTimiliar) }\end{array}$ & $\begin{array}{r}\text { GNPhapits } \\
\text { (USS) }\end{array}$ & $\begin{aligned} \text { GNP Growth } \\
\therefore \quad(x)\end{aligned}$ & $\begin{array}{l}\text { UTANG LK } \\
\text { (UStmillias) }\end{array}$ & $\begin{array}{r}\text { EKSPOR } \\
\text { (USAmatinf) }\end{array}$ & $\begin{array}{r}\text { MPOR } \\
\text { (USTmitsar) }\end{array}$ \\
\hline AMERIKA SEERIKAT & $, 260,6$ & $5.905,0$ & 23240,0 & 4,1 & * & $457, \infty$ & 569,00 \\
\hline AUSTRALU & 18,0 & 304,0 & $17.250,0$ & 4,3 & -1 & 42,00 & 12,00 \\
\hline BRUNA DARUSSALAM & 0,3 & 3,6 & $19.000,0$ & 3,0 & & 3,00 & 3,00 \\
\hline CU & $13,6^{\circ}$ & it & 2730,0 & ti & 19.350 & $9,65^{\circ}$ & $9,45^{\circ}$ \\
\hline can & $1.196,5$ & $2.855,0$ & 470,0 & 11,6 & 69,321 & $90, \infty$ & 100,00 \\
\hline FILPIMA & 65,9 & 159,0 & $\pi 0,0$ & 4, & 32,498 & 11,0 & $17, \infty$ \\
\hline HONGKOHG & 6,1 & 117,0 & $15.360,0$ & 5,5 & & 135,00 & 139,00 \\
\hline DDONESIA & 191,6 & 558,0 & 670,0 & 6,7 & B4,385 & $37,00^{*}$ & $28,00^{\circ}$ \\
\hline JEPAIG & 125,3 & 2510,0 & $28.190,0$ & 0,2 & & 351,00 & 43,00 \\
\hline kavapa & 28,4 & 542,0 & $20.710,0$ & 3,4 & & $.14,00$ & 134,00 \\
\hline KOREA SELATAN & 4,5 & 391,0 & $6.790,0$ & 8,1 & 42,999 & 82,00 & 81,00 \\
\hline MALAYSIA & 19,4 & 151,0 & 2790,0 & $8 ; 1$ & 19,837 & 48,00 & 45,00 \\
\hline IEKSSKO & 86,6 & 634,0 & $3.470,0$ & 3,8 & 113,380 & 47,00 & 50,00 \\
\hline PAPUA NUGNN & 4,2 & 8,2 & 950,0 & $.14,4$ & 3,376 & $1,00^{\circ}$ & $1,54^{*}$ \\
\hline SELANDAA BARU & 3,5 & $\because 50,0$ & 12300,0 & 6,1 & -1 & $10,00^{\circ}$ & $8,00^{\circ}$ \\
\hline SINGAPURA & 3,1 & 52,0 & $15.730,0$ & 9,3 & $\because$ & $74,00^{\circ}$ & $85,00^{\circ}$ \\
\hline TANWAN & 21,0 & 240,0 & $10.210,0$ & 6,1 & 4 & $85, \infty 0$ & $77, \infty$ \\
\hline THAILAND & 59,6 & 340,0 & $1.840,0$ & 7,4 & 39,424 & $37,0^{\circ}$ & 45,00 \\
\hline
\end{tabular}

Koternogan: !

- Tahun 1992

4 Tíak brsodia

Sumber : Dinth daribertagai sumber

dan investasi yang sesuai Deklarasi Bogor telah berjalan nanti.

Dengan adanya komitmen yang kuat dan dunia usaha Indonesia harus mulai berbenah untuk dapat mengantisipasi akibat perjanjian APEC tersebut. Adapun. 
perkembangan perdagangan Indonesia di negara-negara APEC dapat disimak dari tabel 2 di bawah ini: netto positif (surplus) tetapi bila kita ambil hasil pengamatan Karseno AR (Kelola No. 7/III/1994) terlihat daya saing produk In-

Tabel 2 Neraca Perdagangan RI dengan negara-negara APEC tahun 1992 dan 1993 (dalam ribuan dollar AS)

\begin{tabular}{l|r|r|r|r}
\hline \multirow{2}{*}{ NEGARA } & \multicolumn{2}{|c|}{ Tahun 1992 } & \multicolumn{2}{c}{ Tahun 1993 } \\
\cline { 2 - 5 } & \multicolumn{1}{|c|}{ Eksport } & \multicolumn{1}{c|}{ Import } & \multicolumn{1}{c}{ Eksport } & \multicolumn{1}{c}{ Import } \\
\hline Jepang & 10.760 .524 & 6.013 .748 & 10.292 .278 & 5.511 .215 \\
AS & 4.419 .105 & 3.822 .440 & 4.752 .159 & 2.934 .822 \\
Singapura & 3.313 .543 & 1.670 .687 & 3.068 .592 & 1.645 .289 \\
Korsel & 2.083 .284 & 1.894 .104 & 2.017 .174 & 1.922 .082 \\
RRC & 1.396 .437 & 751.517 & 1.159 .150 & 822.271 \\
Hongkong & 881.102 & 228.963 & 820.399 & 226.031 \\
Thailand & 352.799 & 344.658 & 423.314 & 217.927 \\
Filipina & 181.307 & 52.158 & 263.532 & 50.868 \\
Meksiko & 87.323 & 56.099 & 128.262 & 57.348 \\
Papua Nugini & 32.193 & 3.361 & 21.697 & 1.528 \\
Brunei & 25.315 & 706 & 31.080 & .967 \\
Malaysia & 487.535 & 524.574 & 534.693 & 452.401 \\
Taiwan & 1.279 .305 & 1.329 .325 & 1.311 .609 & 1.202 .826 \\
Australia & 746.125 & 1.412 .962 & 723.859 & 1.237 .341 \\
Kanada & 289.032 & 459.331 & 276.667 & 370.001 \\
Selandia Baru & 37.416 & 135.919 & 55.137 & 148.537 \\
Chili & 20.900 & 112.799 & 29.719 & 120.125 \\
\hline
\end{tabular}

Sumber : Departemen Perdagangan 1994

Dari tabel di atas Perdagangan Indonesia ke negara-negara APEC yang cúkup baik adalah ke Jepang, Amerika Serikat dan Singapura, karena dari tahun 1992 ke tahun 1993 mengalami kenaikan yang berarti dan masih surplus perdagangan. Tetapi untuk perdagangan ke negara Australia, Kanada, Selandia Baru dan Chili selama dua tahun tersebut neraca perdagangan Indonesia mengalami defisit. Meskipun perdagangan ke Jepang, Amerika Serikat dan Singapura menunjukkan nilai donesia dari ketiga negara sasaran ekspor tersebut, hanya Amerika Serikat dan Singapura yang mempunyai daya saing positif (kuat), sedangkan untuk negara Jepang mempunyai daya saing yang lemah (negatif). Begitu pula untuk negara Hongkong dan Korea Selatan, daya saing yang dimiliki produk ekspor Indonesia adalah negatif (lemah).

Bilamana pengamatan dilakukan pada komposisi komoditi ekspor Indonesia sebagaimanatercantum pada tabel 3 , terlihat 
masih lemahnya jenis komoditi ekspor Indonesia. Hanya ada 5 (lima) jenis komoditi eksport Indonesia yang dapat mencapai nilai di atas satu milyar dollar AS, yaitu kayu/gabus, pakaian, tekstil, sepatu dan ikan/kerang-kerangan. Tentunya dengan kondisi di atas masih banyak yang perlu dibenahi dari kinerja ekspor Indone-
Denganmelakukan perbaikan dalam semua sektor, pertumbuhan ekonomi Indonesia untuk tahun 1995 diramalkan dapat mencapai 7\%. Ramalan ini diperkirakan dengan memperhitungkan pertumbuhan ekonomi negara-negara di kawasan Asia Pasific yang lebih baik, sehingga ekspor negara Indonesia akan dapat menjadi lebih

Tabel 3 Lima Besar Komoditi Ekspor Indonesia

\begin{tabular}{l|c|c}
\hline \multicolumn{1}{c|}{ Mata Dagangan } & Nilai Eksport & Pangsa Pasar \\
\cline { 2 - 3 } & (dalam miliar USD) & $(\%)$ \\
\hline Kayu / gabus & 5,129 & 18,49 \\
Pakaian & 3,02 & 12,93 \\
Tekstil & 2,64 & 9,74 \\
Sepatu & 1,66 & 3,56 \\
Ikan / kerang-kerang & 1,42 & 2,23 \\
\hline
\end{tabular}

Sumber : Departemen Perdagangan (1993)

sia dalam menyongsong liberalisasi peragangan pada tahun 2020 nanti.

Adapun permasalahan yang harus segera memperoleh perhatian adalah pembenahan industri Indoensia haruslah mulai berorientasi ekspor dengan peningkatan kualitas yang tinggi dan berdaya saing, baik untuk segi promosi, pelaksanaan ekspor dan regulasi perdagangan yang mendukung. Sehingga diperoleh produk eksporyang berdaya saing tinggi dan kinerja ekonomi yang sehat dan efisien. Disamping itu jumlah komoditi ekspor Indonesia yang bersaing sangat tinggi harus mulai diperbanyak, karena dengan diversifikasi yang lebih banyak maka altematif sumber devisa akan lebih bervariasi dan akan memperkecil resiko kehilangan devisa dan memburuknya kondisi neraca perdagangan bilamana terjadi kegoncangan yang mendadak. baik pula. Kondisi ini akan dapat tercapai bilamana semua pihak baik Pemerintah ataupun pihak swasta baik besar, menengah ataupun kecil dapat bekerjasama dan berbenah diri dalam menyongsong liberalisasi perdagangan tersebut dengan 'sekuat tenaga.

Kebijaksanaan regulasi oleh Pemerintah secara konsisten dengan mengurangi segala bentuk kolusi dan kcbijaksanaan dan struktur' "rent seeking economy" yang mendorong ekonomi berbiaya tinggi akan sangat mempengaruhi keberhasilan usaha tersebut. Karena pihak swasta akan dapat berjalan dengan kapasitas riil, efisien dan kempetitif.

Tetapi usaha tersebut di atas akan terpengaruh olch tersedianya infrastruktur. misalnya transportasi, telekomunikasi, listrik ataupun tersedianya jalan. Sedangkan penyediaan infrastruktur tersebut sangat 
ditentukan oleh tersedianya modal untuk investasi.

\section{Perkembangan Investasi Asing}

Kebutuhan investasi di Indonesia untuk mendukung perkembangan perdagangan sangat dirasakan oleh semüa pihak. Oleh karenanya Pemerintah selalu mengevaluasi regulasi tentang penanaman modal asing agar peraturan yang berlaku dapat sèlalu sesuai dengan kondisi yang adả. Begitu pulauntukPaket Kebijaksanaan 23 Oktober 1993 kemudian dievaluasi dan diperbaiki menjadi PP 20 tahun1994, yang telah membuka peluang yang lebih terbuka bagi PMA untukmenanamkan investasinya . di Indonesia. Untuk mengamati perkembanganPMA di Indonesia dari tahun 1989 sampai tahun 1993 dapat dilihat pada tabel 4.
3.983,4 juta dollar AS kemudian mengalami peningkatan pada tahun 1992 dengan jumlah total PMA 7.279,6 juta dollar AS. Tetapi tahun 1993 mengalami penurunan menjadi 4.608,7 juta dollar AS. Melalui PP 20 tahun 1994 diharapkankesempatan yang lebih terbuka dan longgar bagi PMA dapat dimanfaatkan secara optimal oleh invesstor asing, sehingga nilai PMA untuk tahun mendatang akan dapat meningkat lagi.

- Dari segi lokasi penempatan investasi di Indonesia juga masih perlu dilakukan pembenahan. Karena dari data BKPM tahun 1993 hampir 60 persen lokasi yang tergarap oleh PMA berada di Kawasan Indonesia bagian Barat. Tentunya kondisi ini tidaklah dapat dibiarkan, karena untuk dapat menumbuhkan perekonomian yang merata maka lokasi pembangunan infrastruktur juga harus merata. Sehingga usaha-usaha

Tabel 4 Investasi Asing di Indonesia (dalam juta dollar AS)

\begin{tabular}{|c|c|c|c|c|c|c|}
\hline Negara & & 1989 & 1990 & 1991 & 1992 & 1993 \\
\hline $\begin{array}{l}\text { Jepang } \\
\text { Korsel } \\
\text { Hongkong } \\
\text { Taiwan } \\
\text { Singapura } \\
\text { AS } \\
\text { Belanda } \\
\text { Inggris } \\
\text { Australia } \\
\text { Jerman }\end{array}$ & - & $\begin{array}{r}778,6 \\
466,1 \\
401,5 \\
156,9 \\
156,2 \\
348,1 \\
282,8 \\
43,5 \\
41,7 \\
6,7\end{array}$ & $\begin{array}{r}2.240,8 \\
722,9 \\
993,3 \\
618,3 \\
265,2 \\
153,7 \\
576,2 \\
59,0 \\
186,5 \\
13,5\end{array}$ & $\begin{array}{r}929,3 \\
301,3 \\
227,7 \\
1.057,5 \\
364,4 \\
275,6 \\
183,6 \\
535,7 \\
48,4 \\
59,9\end{array}$ & $\begin{array}{r}2.510,6 \\
618,3 \\
1.020,9 \\
563,3 \\
465,1 \\
922,5 \\
96,2 \\
978,2 \\
67,8 \\
-\quad 36,7\end{array}$ & $\begin{array}{r}815,0 \\
660,4 \\
470,6 \\
124,6 \\
1.333,2 \\
-445,3 \\
311,0 \\
310,1 \\
118,2 \\
-\quad 20,3\end{array}$ \\
\hline
\end{tabular}

Sumber : BKPM, April 1994

Melihat perkembangan jumlah investasi oleh PMA di atas cukup menggembirakan karena secara total walaupun terjadi fluktuasi, jumlah PMA masihmenunjukkan nilai yang cukup besar. Pada tahun 1991 júmlahnya mencapai di Kawasan Indonesia bagian Tímür yang berpotensi, akan dapat tumbuh menjadi usaha yang potensial dan berdaya saing tinggi serta dapat tumbuh dan berkembang sebagaimana usaha-usaha di Kawasan Indonesia bagian Barat. 
Kesimpulan

Prosepek perdagangan Indonesia ke negara-negara APEC sangat baik, namun di sisi lain masih banyak hal yang harus dibenahi dalam produk Indonesia agardapat mempunyai daya saing yang kuat. Ada beberapa penyebab yang patut diperhatikan dalam rangka meningkatkan daya saing tersebut yaitu rendahnya kualitas produk jadi Indonesia dalam persaingannya dengan produk pesaing yang disebabkan masih rendahnya kontrol kualitasolehmanufactur. Inefisiensi dalam kinerja ekonomi masih dijumpai karena masih terjadinya monopoli ataupun oligopoli dalam usaha, sehingga kemampuan kompetisi dalam liberalisasi perdagangan masih lemah.

Antisipasi pasar yang tepat melalui usaha memperoleh informasi pasar yang akurat dan cepat perlu memperoleh perhatian dunia usaha Indonesia. Karena persaingan yang semakin ketat memerlukan pengambilan keputusan yang cepat dan akurat. Meskipun produk yang disiapkan adalah untuk bersaing dengan produk pesaing itu berarti pasar yang diarah adalah pasarekspor dan dalam negeri. Pasarekspor diharapkan dapatmeningkatkan penyediaan devisa sedangkan pasar dalam negeri harus tetap dijaga dari serbuan produk-produk impor yang tidak boleh ada hambatan lagi masuk ke negeri ini.
Penyediaan infrastruktur juga harus diperhatikan, karena hanya dengan penyedir.an infrastruktur yang baik dapat mendukung kegiatan ekonomi nasional. Pertumbuhan dan peluang ekonomi akan dapat meningkatkan investasi, tetapi harus tetap diperhatikan daya tampungnya, sehingga kondisi tersebut tidak mengakibatkan adanyạ "overheated" dalam perekonomian Indonesia. Investasi yang berkembang cepat juga hanis tetap dijaga dari sisi impor, sehingga defisit transaksi berjalan yang merupakan titik rawan dalam neraca perdagangan Indonesia tidak menjadi parah, tetapi dengan perbaikan kinerjà ekonomi nasional itulah justru dihärapkan terjadi perbaikan pada neraca perdagangan Indonesia.

Pemerintah harus terus melakukan deregulasi yang dapat mendukung perbaikan kinerja ekonomi nasional. Sehingga ekonomi biaya tinggi yang masih menghinggapi perekonomian kita dapat dihilangkan yaitu dengan mengikis praktek kolusi, proteksi, monopoli dan kapitalisme semu yang sesungguhnya membebani masyarakat, karena membuat kegiatan ekonomi menjadi tidak efisien serta produk yang dihasilkan menjadi kurang berdaya saing, baik di pasar dalam negeri maupun di luar negeri. 


\section{Referensi}

Centre for Strategic and International Studies (CSIS), Indonesian Perspectives on APEC and Regional Cooperation in Asia Pacific", Jakarta, 1994.

El-Agraa, Ali (ed), International Economic Integration, The Mac Milan Press Lid, London, 1988.

Karseno AR, "Perdagangan Indonesia dengan Negara-ñegara ASEAN dan 'APEC",
Kelola nomor 7/1II/1994, Gadjah Mada University Business Review, Yogyakarta, 1994.

Surat Kabar dan Majalah:

1. Harian Bisnis Indonesia, berbagai edisi

2. Hariañ $\dot{K} o m p a s$, berbagai edisi

3. Harian Kedaulalan Rakyá, berbagai edisi

4. Majalah Warla Ekonomi, berbagai edisi 